\title{
Perinatal acquisition of drug-resistant HIV-I infection: mechanisms and long-term outcome
}

Constance Delaugerre*1,2, Marie-Laure Chaix ${ }^{1,2}$, Stephane Blanche ${ }^{3,2}$, Josiane Warszawski ${ }^{4}$, Dorine Cornet ${ }^{2}$, Catherine Dollfus ${ }^{5}$, Veronique Schneider ${ }^{6}$, Marianne Burgard ${ }^{2}$, Albert Faye ${ }^{7}$, Laurent Mandelbrot ${ }^{8}$, Roland Tubiana ${ }^{9}$, Christine Rouzioux ${ }^{1,2}$ and the ANRS
French Perinatal Cohort

Address: ${ }^{1}$ EA 3620 MRT, Descartes University, Paris, France, 2 2Virology Department, Necker-Enfants Malades Hospital-APHP, Paris, France, ${ }^{3}$ Hematology Immunology Peadiatric Department, Necker-Enfants Malades Hospital-APHP, Paris, France, ${ }^{4}$ INSERM unit U822, University ParisSud, Le Kremlin Bicêtre, France, ${ }^{5}$ Pediatric and Oncology Department, Trousseau Hospital-APHP, Paris, France, ${ }^{6}$ Virology Department, Tenon Hospital-APHP, Paris, France, ${ }^{7}$ Hematology Immunology Peadiatric Department, Robert Debre Hospital-APHP, Paris, France, ${ }^{8}$ Gynecology Obstetric Department, Louis Mourier Hospital-APHP, Colombes, France and 'Infectious Diseases Department, Pitie Salpetriere Hospital-APHP, Paris, France

Email: Constance Delaugerre* - constance.delaugerre@sls.aphp.fr; Marie-Laure Chaix - marie-laure.chaix@nck.aphp.fr; Stephane Blanche - stephane.blanche@nck.aphp.fr; Josiane Warszawski - warszaws@vjf.inserm.fr; Dorine Cornet - dorine.cornet@nck.aphp.fr; Catherine Dollfus - catherine.dollfus@trs.aphp.fr; Veronique Schneider - veronique.schneider@tnn.aphp.fr; Marianne Burgard - marianne.burgard@nck.aphp.fr; Albert Faye - albert.faye@rdb.aphp.fr; Laurent Mandelbrot - laurent.mandelbrot@lmr.aphp.fr; Roland Tubiana - roland.tubiana@psl.aphp.fr;

Christine Rouzioux - christine.rouzioux@nck.aphp.fr; the ANRS French Perinatal Cohort - warszaws@vjf.inserm.fr

* Corresponding author

Published: 19 September 2009

Retrovirology 2009, 6:85 doi:10.1186/1742-4690-6-85

This article is available from: http://www.retrovirology.com/content/6/I/85

(c) 2009 Delaugerre et al; licensee BioMed Central Ltd.

This is an Open Access article distributed under the terms of the Creative Commons Attribution License (http://creativecommons.org/licenses/by/2.0), which permits unrestricted use, distribution, and reproduction in any medium, provided the original work is properly cited.
Received: 29 April 2009

Accepted: 19 September 2009

\begin{abstract}
Background: Primary-HIV-I-infection in newborns that occurs under antiretroviral prophylaxis that is a high risk of drug-resistance acquisition. We examine the frequency and the mechanisms of resistance acquisition at the time of infection in newborns.

Patients and Methods: We studied HIV-I-infected infants born between 0 I January 1997 and 3I December 2004 and enrolled in the ANRS-EPF cohort. HIV-I-RNA and HIV-I-DNA samples obtained perinatally from the newborn and mother were subjected to population-based and clonal analyses of drug resistance. If positive, serial samples were obtained from the child for resistance testing.

Results: Ninety-two HIV-I-infected infants were born during the study period. Samples were obtained from 32 mother-child pairs and from another 28 newborns. Drug resistance was detected in 12 newborns (20\%): drug resistance to nucleoside reverse transcriptase inhibitors was seen in 10 cases, non-nucleoside reverse transcriptase inhibitors in two cases, and protease inhibitors in one case. For 9 children, the detection of the same resistance mutations in mothers' samples (6 among 10 available) and in newborn lymphocytes (6/8) suggests that the newborn was initially infected by a drug-resistant strain. Resistance variants were either transmitted from mother-tochild or selected during subsequent temporal exposure under suboptimal perinatal prophylaxis. Follow-up studies of the infants showed that the resistance pattern remained stable over time,
\end{abstract}


regardless of antiretroviral therapy, suggesting the early cellular archiving of resistant viruses. The absence of resistance in the mother of the other three children $(3 / 10)$ and neonatal lymphocytes $(2 / 8)$ suggests that the newborns were infected by a wild-type strain without long-term persistence of resistance when suboptimal prophylaxis was stopped.

Conclusion: This study confirms the importance of early resistance genotyping of HIV-I-infected newborns. In most cases (75\%), drug resistance was archived in the cellular reservoir and persisted during infancy, with or without antiretroviral treatment. This finding stresses the need for effective antiretroviral treatment of pregnant women.

\section{Background}

Mother-to-child transmission (MTCT) of HIV-1 mainly occurs during the third trimester of pregnancy or at delivery, in the absence of breastfeeding [1]. Transmission can be prevented by treating the pregnant woman during the third trimester and at delivery, and by giving the child prophylactic treatment during the first weeks of life. The efficacy of this approach was first demonstrated in 1994 with zidovudine [2], and the transmission rate has gradually fallen in Europe and the United States from 25\% to below $2 \%[3,4]$. French guidelines published in 2004 recommend starting combination antiretroviral therapy (HAART) at the end of the second trimester and adding intravenous zidovudine (ZDV) during labor. Infants receive ZDV orally for 6 weeks, alone or combined with other antiretroviral drugs if the risk of transmission is high [5].

Situations of particular risk of HIV-1 MTCT [4] include unknown maternal HIV-1 serostatus; ineffective maternal ART; maternal primary HIV-1 infection during pregnancy; and suboptimal MTCT prevention.

Infants may be at an increased risk of infection by drugresistant HIV-1 strains when the mother harbors such viruses or when drug pressure during MTCT prophylaxis is suboptimal.

Vertical transmission of drug-resistant HIV-1 was first reported sporadically [6-8], but it is now known that $9 \%$ to $30 \%$ of infected infants exposed to MTCT prophylaxis with ZDV acquire ZDV-resistant viruses [7,9-12]. Masquelier et al. reported finding viruses with ZDV genotypic resistance in $20 \%$ of $34 \mathrm{HIV}$-1-infected infants who were born in France between 1994 and 1996 and were enrolled in the ANRS-EPF French national cohort [7]. In New York State, drug resistance mutations were detected in $12 \%$ of perinatally infected infants born in 1998 and 1999 [13] and in $19.1 \%$ of such infants born in 2001 and 2002 [14].

In France, between 1997 and 2004, the estimated MTCT rate was $1.8 \%$ (92 newborns). Here we report the current rate of HIV-1 drug resistance in French neonates born to infected mothers. We also report our investigation as to how these resistant viruses were acquired by the newborns, and the outcome of resistance during infancy.

\section{Patients and methods Study population}

Since 1985, the ANRS French Perinatal Cohort (CO 01ANRS-EPF, Agence Nationale de Recherche sur le SIDAEnquête Périnatale Française) has prospectively collected data on HIV-infected pregnant women and their children in 90 centers throughout France. Informed consent is obtained from the mothers during pregnancy or at the time of delivery. The children receive standard care, including clinical and biological examinations at birth and 1, 3, 6, 12 and 18-24 months, as previously reported [15]. The cohort study was approved by the Cochin Hospital Institutional Review Board and by the French computer database watchdog commission (CNIL). Mother and infant plasma and cells were collected between 1990 and 2005 and stored in Necker hospital virology laboratory.

HIV-1 infection was diagnosed in the newborn when at least two separate samples were positive by HIV-1 RNA/ DNA detection or by a viral culture. A positive test at birth or before 7 days of age indicates intrauterine transmission, while a negative test at birth and a positive test more than 7 days later indicate intrapartum transmission. An infant is considered uninfected when two tests performed one month after discontinuation of antiretroviral prophylaxis are negative.

Newborns were included in this analysis if: (1) they were born and enrolled in metropolitan France in centers participating in the EPF cohort between 1997 and 2004; (2) they were HIV-1-infected; and (3) if frozen samples were available for resistance testing.

For each mother-child pair, we analyzed the first available HIV-1-positive sample(s) from the infant's delivery sample and the mother's. If drug resistance was detected in the newborn diagnostic sample, available follow-up samples from the infant were tested for genotypic resistance. 
Other data, including the mothers' viral load values and the mothers' and infants' antiretroviral treatment histories, were obtained from the ANRS-EPF database.

\section{HIV-I RNA quantification}

Plasma HIV-1 RNA was quantified with the Cobas Amplicor HIV-1 Monitor 1.5 assay kit (Roche Diagnostics, Meylan, France; detection limit 400 or 40 copies/mL).

\section{Resistance genotyping}

The ANRS consensus method was used for populationbased nucleotide sequence analysis of the whole protease gene (codons 1 to 99) and codons 1 to 305 of the reverse transcriptase gene on HIV-1 RNA in plasma and HIV-1 DNA in PBMC [16]. Drug resistance mutations were identified by following the International AIDS Society-USA 2007 Drug Resistance Group guidelines [17] http:// www.iasusa.org. Specifically, we considered the following mutations (relative to the reference wild-type (WT) strain HXB2): protease inhibitors (PI): D30N, L33F/I, M46I/L, G48V, I50L/V, V82A/F/L/S/T, I84A/C/V, and L90M; nucleoside reverse transcriptase inhibitors (NRTI): M41L, A62V, K65R, D67N, K70R, L74V, V75I, F77L, Y115F, F116Y, Q151M, M184V, L210W, T215Y/F/C/D/E/S/I/V/ $\mathrm{A} / \mathrm{G} / \mathrm{H} / \mathrm{L} / \mathrm{N}$ and $\mathrm{K} 219 \mathrm{E} / \mathrm{Q} / \mathrm{R}$; and non nucleoside reverse transcriptase inhibitors (NNRTI): L100I, K103N, V106A/ M, V108I, Y181C/I, Y188C/H/L, G190A/S, P225H, M230L, and P236L. Mixtures of WT and mutant sequences were considered drug-resistant. Interpretation of genotypic drug susceptibility was done according to the 2007 French ANRS algorithm http://www.hivfrenchresist ance.org.

\section{Clonal analysis of resistance in three mother-child pairs} In order to characterize the plasma and cellular viral quasispecies, clonal analyses were performed on samples from three mother-child pairs. The maternal samples were obtained at delivery and the children's samples were obtained both at birth and subsequently. These three pairs were chosen as being representative of three different situations, and because suitable plasma/cell samples for them were available. The RT or protease gene was amplified. Purified PCR products were cloned into the pCR Topo 2-1 plasmid (TOPO TA Cloning kits, Invitrogen BV, the Netherlands) as recommended by the manufacturer. DNA was purified with the Mini-Prep kit (Qiagen) and clones were analyzed by dye terminator sequencing on an ABI Prism 3100 genetic analyzer.

\section{Phylogenetic analysis}

Mother-child clustering of pol sequences was confirmed by phylogenetic analysis. All sequences of HIV-1 RNA and DNA clones from each mother-child pair were aligned with Clustal W 1.7 software. Pairwise evolutionary distances were estimated with DNADist using Kimura's two- parameter method. The phylogenetic trees were then constructed with a neighbor joining method (Neighbor program implemented in the Phylip package) [18]. The reliability of each tree topology was estimated from 100 bootstrap replicates [18].

\section{Results \\ Study population}

From January 1997 to December 2004, 6170 motherchild pairs were enrolled in the ANRS-EPF cohort, representing approximately $70 \%$ of births to HIV-1-infected mothers in France. 92 newborns were infected during this period despite prophylaxis. It is important to note that the newborn samples were used to diagnose HIV infection and that the remaining stored samples were usually very limited.

HIV-1-positive plasma and/or PBMC samples from 60 children (33 boys and 27 girls) were available for drug resistance studies. Samples were also available from 32 of these children's mothers. The children's samples were obtained at a median age of 29 days ( 1 to 313 days), and $72 \%$ of plasma samples were collected less than 60 days after birth. The children's median HIV-1 RNA viral load at diagnosis was $4.5 \log _{10}$ copies/ml (2.1 to $\left.7.3 \log _{10}\right)$.

\section{Drug resistance at HIV-I diagnosis in the infant}

Twelve (20\%) of the 60 newborns had resistant variants at diagnosis of HIV-1 infection, according to the 2007 IAS (International AIDS Society) list (Table 1). Six of these children were infected in utero and four intrapartum; the timing of infection could not be determined in the remaining two children as no birth sample was available. The mutations were associated with resistance to NRTI in 10 cases [thymidine analog mutations (TAMs) in six cases, T69N in one case, $\mathrm{M} 184 \mathrm{~V}$ in one case, and both mutations in two cases], NNRTI in two cases, and PI in one case.

According to the 2007 ANRS algorithm, 6 of the 12 children had variants with resistance to at least one antiretroviral drug [overall frequency $10 \%(6 / 60)$ ]. Resistance to NRTI, NNRTI and PI was observed in four children, two children and one child, respectively. One child had variants resistant to both NRTI and NNRTI (child \#10, Table 1).

In all but one case, the neonates' drug resistance profiles were related to the antiretroviral drugs received by the mother and/or by the child (Table 1). Infant \#10 harbored viruses with mutations associated with NNRTI resistance, without being exposed perinatally to this drug class. His mother had never received NNRTI, but she had probably been infected with NNRTI-resistant virus transmitted by her husband, who was treated with a regimen containing nevirapine, stavudine and lamivudine. 
Table I: Perinatal antiretroviral exposition and drug resistance mutations in newborns and their respective mother

\begin{tabular}{|c|c|c|c|c|c|c|c|c|c|c|}
\hline \multirow{3}{*}{ Newborn } & \multirow{3}{*}{ Birthyear } & \multicolumn{3}{|c|}{ Antiretroviral perinatal exposition } & \multirow{3}{*}{$\begin{array}{c}\text { HIV-I } \\
\text { diagnosis } \\
\text { sample }\end{array}$} & \multirow{3}{*}{$\begin{array}{c}\text { Viral } \\
\text { subtype }\end{array}$} & \multicolumn{4}{|c|}{ HIV-I drug-resistance mutations* } \\
\hline & & \multirow[t]{2}{*}{ Mother } & \multirow[t]{2}{*}{ Intrapartum } & \multirow[t]{2}{*}{ Newborn } & & & \multicolumn{2}{|c|}{ in Newborns } & \multicolumn{2}{|c|}{ in Mothers } \\
\hline & & & & & & & $\begin{array}{l}\text { HIV-I } \\
\text { RNA }\end{array}$ & $\begin{array}{l}\text { HIV-I } \\
\text { DNA }\end{array}$ & $\begin{array}{l}\text { HIV-I } \\
\text { RNA }\end{array}$ & $\begin{array}{l}\text { HIV-I } \\
\text { DNA }\end{array}$ \\
\hline 1 & 1997 & ZDV & NA & ZDV & I mo & B & $70 R$ & $70 R$ & $70 \mathrm{R} / \mathrm{K}$ & $70 \mathrm{R} / \mathrm{K}$ \\
\hline 2 & 1997 & ZDV 3TC & ZDV & ZDV 3TC & birth & NA & $4 \mathrm{IL}, \mathrm{I} 84 \mathrm{~V}$ & NA & $\begin{array}{l}4 I \mathrm{~L}, \mathrm{I} 84 \mathrm{~V} \\
2 \mathrm{I} \mathrm{YY} / \mathrm{F}\end{array}$ & NA \\
\hline 3 & 1997 & ZDV 3TC & ZDV & ZDV 3TC & I mo\# & NA & $70 \mathrm{R}, 184 \mathrm{~V}$ & NA & $70 \mathrm{R}, 184 \mathrm{~V}$ & NA \\
\hline 4 & 1998 & - & - & ZDV & I mo & CRF02 & $219 \mathrm{Q} / \mathrm{K}$ & NA & $181 \mathrm{C}$ & $\begin{array}{c}\text { No } \\
\text { mutation }\end{array}$ \\
\hline 5 & 1999 & ZDV & - & ZDV & I mo & B & $70 R$ & $70 R$ & NA & NA \\
\hline 6 & 1999 & - & NA & ZDV & birth & $\mathrm{F}$ & $67 \mathrm{~N} / \mathrm{S}$ & $\begin{array}{c}\text { no } \\
\text { mutation }\end{array}$ & $\begin{array}{c}\text { no } \\
\text { mutation }\end{array}$ & $\begin{array}{c}\text { no } \\
\text { mutation }\end{array}$ \\
\hline 7 & 2000 & $\begin{array}{c}\text { ZDV 3TC } \\
\text { DDI }\end{array}$ & ZDV & ZDV & birth & CRF02 & $69 \mathrm{~N}$ & $69 \mathrm{~N}$ & $69 \mathrm{~N}$ & $69 N$ \\
\hline 8 & 2001 & $\begin{array}{l}\text { ZDV DDI } \\
\text { NVP }\end{array}$ & ZDV & ZDV & $1 \mathrm{mo}$ & B & IOIE, I90A & IOIE, I90A & NA & NA \\
\hline \multirow[t]{2}{*}{9} & 2001 & $\begin{array}{c}\text { DDI SQV } \\
\text { LPV/R }\end{array}$ & ZDV & ZDV & birth & B & $\begin{array}{l}(\mathrm{RT}) \text { no } \\
\text { mutation }\end{array}$ & $\begin{array}{c}(\mathrm{RT}) \text { no } \\
\text { mutation }\end{array}$ & $\begin{array}{c}\text { (RT) I I IC } \\
210 \mathrm{~W} \\
215 \mathrm{D}\end{array}$ & $\begin{array}{c}\text { (RT) } 181 \mathrm{Cl} / \\
\mathrm{Y} 210 \mathrm{~W} / \mathrm{L} \\
215 \mathrm{~N} / \mathrm{T}\end{array}$ \\
\hline & & & & & & & $\begin{array}{l}\text { (P) } 10163 \mathrm{P} \\
90 \mathrm{M}\end{array}$ & $\begin{array}{l}\text { (P) } 10163 \mathrm{P} \\
90 \mathrm{M}\end{array}$ & $\begin{array}{l}\text { (P) I0I 63P } \\
90 M 215 Y\end{array}$ & $\begin{array}{l}\text { (P) } 10163 P \\
90 M\end{array}$ \\
\hline 10 & 2001 & - & ZDV & ZDV & $3 \mathrm{mo \#}$ & CRF02 & $103 \mathrm{~N} I 8 \mathrm{IC}$ & NA & $\begin{array}{c}103 N \mid 8 I C \\
215 Y\end{array}$ & NA \\
\hline 11 & 2004 & $\begin{array}{c}\text { ZDV 3TC } \\
\text { IDV/R }\end{array}$ & ZDV & ZDV 3TC & birth & B & $184 \mathrm{~V}$ & $184 \mathrm{~V}$ & $\begin{array}{c}\text { no } \\
\text { mutation }\end{array}$ & NA \\
\hline 12 & 2004 & $\begin{array}{c}\text { ZDV 3TC } \\
\text { IDV/R }\end{array}$ & ZDV & ZDV & birth & A & $70 \mathrm{R} / \mathrm{K}$ & $\begin{array}{c}\text { no } \\
\text { mutation }\end{array}$ & $\begin{array}{c}\text { no } \\
\text { mutation }\end{array}$ & $\begin{array}{c}\text { no } \\
\text { mutation }\end{array}$ \\
\hline
\end{tabular}

\footnotetext{
* Genotypic analysis of resistance was performed on the HIV-I diagnosis sample for the children (except for child \#I I, in whom resistance was analyzed at month 3 ) and at delivery for the mother Resistance mutations according to the IAS list 2007 were noted ((RT) reverse transcriptase; (P) protease)

ZDV = zidovudine, 3TC = lamivudine, DDI = didanosine, NVP = nevirapine, SQV = saquinavir, LPV/R = lopinavir/ritonavir, IDV/R = indinavir/ritonavir, dash "-" = untreated

\# no prior available sample

NA not available
}

The viral subtypes were determined in 53 children, and were subtype CRF02_AG in 23 cases (43\%), B in 19 cases (36\%), A in 5 cases ( $9 \%$ ) and another subtype in 6 cases (11\%). Among the 10 subtyped resistant viruses, 5 (50\%) belonged to subtype B, three (30\%) to CRF02_AG, one to $\mathrm{A}$ and one to $\mathrm{F}$.

DNA-based resistance results were available for 8 of the 12 children with resistant viruses in plasma. In 6 cases HIV-1 RNA and DNA harbored the same resistance mutations (Table 1), while no mutation was detected in HIV-1 DNA in the other two cases.

\section{Comparison of resistance mutations in the children and their mothers}

Samples from 32 mother-child pairs were available, including 10 of the 12 children with resistant virus in the plasma (Table 1). The resistance pattern was the same in six mother-child pairs. In the remaining four cases the mothers harbored different mutations or no mutation. Interestingly, child \#9, whose mother harbored PI resistance mutations L10I, L63P and L90M and RT resistance mutations Y181C, L210W and T215D, only harbored the PI resistance mutations. The mother was receiving didanosine, saquinavir and lopinavir/ritonavir, probably leading to the selection of a dominant PI-resistant quasispecies. Among the 22 remaining mother-child pairs, 20 mothers had wild-type viruses (in plasma), while the other two mothers harbored resistant viruses that were not transmitted to the child.

\section{Longitudinal resistance analysis in infected children}

Longitudinal resistance studies were performed in 8 of the 12 cases in which serial samples were available (median 4 samples per child), over a median period of 52 months (Table 2). The same resistance mutations persisted in the plasma and PBMC for 6 months to 5 years, regardless of the antiretrovirals used in six children. Additional mutations had accumulated in the RNA and the DNA during failing regimens. In two children (\#6, \#12), no zidovudine resistance mutations were detected when zidovudine prophylaxis was discontinued. Interestingly, no resistance mutations were detected in mother samples and in birth children cells (Table 1 and 2). 
Clonal and phylogenetic analysis of HIV-I in three mothernewborn pairs

To better understand how drug-resistant HIV-1 strains detected in newborns are acquired, we conducted clonal analyses of plasma and PBMC viral populations in three mother-child pairs. The maternal samples were taken at delivery, and the children's samples were taken both at birth and at a later time.

In mother-child pair \#9, 110 protease gene clones were sequenced (Figure 1). In the mother, all 21 plasma clones harbored the L90M major mutation and other minor mutations. Her PBMC harbored heterogeneous variants (12/21 wild-type, 8/21 L90M and 1/21 I84V), according to the temporal archiving of resistant variants in lymphocytes during therapeutic regimens that contrasted with the homogeneity reported in the plasma under selective therapeutic pressure. In her child, who was infected in utero, all plasma and cellular variants harbored the L90M mutation (40/40 at birth and 28/28 at month 30), even during the period without PI selective pressure. Phylogenetic analysis confirmed the homogeneity of the child's specimens at birth with a genetic intravariability of protease gene that increased over time (from $0.003 \%$ to $0.01 \%)$. This case suggests the perinatal transmission of L90M variants with early archiving in the child's lymphocytes and persistence over time.

In mother-child pair \#11, 70 RT gene clones were sequenced (Figure 2). The mother acquired HIV-1 infection during pregnancy and was rapidly treated with zidovudine, lamivudine and indinavir/ritonavir. The child was infected in utero, despite elective Cesarean section and the intensification of postnatal zidovudine prophylaxis by the addition of lamivudine. All plasma and cellular quasispecies detected in the newborn (35/35 at month 3 and 26/ 26 at month 7) harbored the $\mathrm{M} 184 \mathrm{~V}$ lamivudine resistance mutation. However, this mutation was not detected in the mother's delivery plasma sample ( $9 / 9$ wild-type). Phylogenetic analysis confirmed low genetic intravariability (mean $0.006 \%$ ) of the RT gene in the mother and her child, in keeping with the high homogeneity due to the primary infection in the child and his mother. M184V variants may have arisen during lamivudine treatment of the mother and prophylaxis of the infant, leading to the massive early lymphocyte infection and persistence of lamivudine resistance. However, we cannot exclude an abacavirselective pressure on the $M 184 \mathrm{~V}$ resistance-associated mutation or a minor maternal $\mathrm{M} 184 \mathrm{~V}$ variant transmission.

In mother-child pair \#12, 61 RT gene clones were sequenced (Figure 3 ). The mother had advanced HIV-1 disease and poor adherence to treatment as reflected by high viral load $\left(4.4 \log _{10}\right.$ copies/mL). Resistance was undetectable even by clonal analysis (28/28 wild-type). Zidovudine prophylaxis was initiated at birth and continued for 6 weeks despite the diagnosis of HIV-1 in utero infection in the newborn. In the child, the K70R mutation was detected in $42 \%$ of clones (10/24) at month 1 and in $0 \%$ at month 12 . Genetic intravariability was low $(0.005 \%)$ in the child, as expected, during primary infection. In this case, wild-type viruses were detected concomitantly in the RNA from the mother and in the DNA from the child (only $1 / 10$ resistant clones), suggesting that most archived viruses in the child were WT viruses transmitted by the mother. Zidovudine resistance, present at the time of diagnosis, occurred during suboptimal zidovudine pressure. Zidovudine discontinuation led to the re-emergence of wild-type variants in the plasma at month 12 , confirming that the reservoir consisted mainly of wildtype viruses.

\section{Discussion}

In France, early strategies intended to prevent vertical HIV transmission are now considered suboptimal until the recommendations of HAART in 2004 [5]. Indeed, newborns are at a high risk of acquiring drug resistant variants emerging from their primary HIV-1 infection under antiretroviral selective pressure [19].

In this study, we retrospectively detected resistance mutations in 20\% of children born between 1997 and 2004 who were enrolled in the ANRS-EPF cohort. Interestingly, the same frequency ( 7 of $34,20 \%$ ) was noted in the same cohort during the period 1994-1996 [7], even though the rate of vertical transmission was lower in the more recent period. However, whereas only zidovudine resistance was detected in 1994-1996, more varied resistance profiles were found in 1997-2004, owing to the increased diversity of antiretroviral combinations used to treat pregnant HIV1-infected women. Resistance to NRTI remained predominant throughout the study period. The most frequent mutations were those associated with resistance to zidovudine and lamivudine, which are the only antiretroviral drugs licensed for use in neonates. Only 3\% of the children $(n=2)$ harbored variants resistant to NNRTI, compared to $12 \%$ in American studies [13,14], probably owing to more widespread use of NNRTI-containing regimens to treat pregnant women in the USA [20]. In our study, only one child had PI resistance mutations, reflecting the recent recommendation of PI-containing regimens for PMTCT and a higher genetic barrier to resistance with ritonavir-boosted PI-containing regimens.

In most of the children studied here, the resistance profiles were related to antenatal and post partum antiretroviral drug exposure. This contrasts with the lack of relationship between antiretroviral drug resistance in newborns and perinatal antiretroviral exposure observed 
Table 2: Longitudinal resistance analysis in newborns infected with drug resistant HIV-I

PERSISTENCE OF RESISTANCE MUTATION

\begin{tabular}{|c|c|c|c|c|c|c|}
\hline \multirow[b]{2}{*}{ Patient } & \multirow[b]{2}{*}{ Birth year } & \multirow[b]{2}{*}{$\begin{array}{l}\text { Antiretroviral } \\
\text { regimen }\end{array}$} & \multirow[b]{2}{*}{$\begin{array}{l}\text { HIV-I diagnosis } \\
\text { sample }\end{array}$} & \multirow[b]{2}{*}{$\begin{array}{l}\text { Resistance sample } \\
\text { (Month) }\end{array}$} & \multicolumn{2}{|c|}{ Resistance mutations in children } \\
\hline & & & & & HIV-I RNA & HIV-I DNA \\
\hline \multirow[t]{4}{*}{$\mathbf{I}$} & 1997 & ZDV & Month I & MI & 70R & 70R \\
\hline & & ZDV d4T ddl & & M4 & & 70R \\
\hline & & stop & & M36 & 67N 70R $219 E$ & \\
\hline & & d4T ddl EFV & & M48 & & $\begin{array}{c}\text { 67N 70R I0IE/K 103N/ } \\
\text { K 190S/G } 219 \mathrm{E}\end{array}$ \\
\hline \multirow[t]{5}{*}{7} & 2000 & & Birth & MO & $(\mathrm{RT}) \mathbf{6 9 N}$ & $69 N$ \\
\hline & & d4T 3TC NFV NVP & & $M 20$ & $\begin{array}{l}\text { (RT) } 69 \mathrm{~N} 103 \mathrm{~N} \\
\quad 81 \mathrm{C} 184 \mathrm{~V}\end{array}$ & \\
\hline & & $3 T C N V P$ & & M26 & $\begin{array}{c}\text { (RT) 69N I8IC I84I } \\
\text { (P) } 2013617 \mid \mathrm{T} / \mathrm{A} \\
90 \mathrm{M} / \mathrm{L}\end{array}$ & \\
\hline & & stop & & M50 & $\begin{array}{l}\text { (RT) 69N } 181 \mathrm{C} \\
\text { (P) } 201361\end{array}$ & \\
\hline & & stop & & M58 & $\begin{array}{l}\text { (RT) } 69 \mathrm{~N} I 8 I \mathrm{C} \\
\text { (P) } 201361\end{array}$ & \\
\hline \multirow[t]{6}{*}{8} & 2001 & ZDV & Month I & MI & IOIE I9OA & IOIE I9OA \\
\hline & & stop & & M4 & IOIE I9OA & \\
\hline & & $\mathrm{d} 4 \mathrm{~T}$ 3TC LPV/r & & MI2 & IOIE I84V I90A & \\
\hline & & $\mathrm{d} 4 \mathrm{~T}$ 3TC LPV/r & & M36 & & IOIE I06I/V I90A \\
\hline & & $\mathrm{d} 4 \mathrm{~T}$ 3TC LPV/r & & M48 & IOIE I84V I90A & IOIE I06I I90A I84V \\
\hline & & $\mathrm{d} 4 \mathrm{~T}$ 3TC LPV/r & & M55 & I84V I90A & \\
\hline \multirow[t]{15}{*}{9} & 2001 & ZDV & Birth & MO & (P) I0I 63P 90M & (P) I0I 63P 90M \\
\hline & & d4T ABC NVP & & MI & (P) $10163 P 90 M$ & \\
\hline & & stop & & MI2 & & (P) $10163 P 90 M$ \\
\hline & & ABC 3TC NFV NVP & & MI8 & (RT) I8IC I84V & \\
\hline & & & & & (P) $10163 P 90 M$ & \\
\hline & & ABC 3TC NFV NVP & & $M 20$ & (RT) $181 \mathrm{C} 184 \mathrm{~V}$ & \\
\hline & & & & & (P) $10163 P 90 M$ & \\
\hline & & $\mathrm{d} 4 \mathrm{~T} \mathrm{ABC} L \mathrm{LPV} / \mathrm{r}$ & & M32 & (RT) I8IC I84V & \\
\hline & & & & & (P) 101 63P 7IT 90M & \\
\hline & & stop & & M38 & (RT) $I 0 I R / K \quad I 8 I C / Y$ & \\
\hline & & & & & (P) I0I 63P 7IT 90M & \\
\hline & & ZDV ABC ATV/r & & M48 & (RT) $10|R / K 2| 5 \mid / T$ & (RT) $|0| R / K 2|5| / T$ \\
\hline & & & & & (P) $10163 \mathrm{P} 71 \mathrm{~T} 90 \mathrm{M}$ & (P) I0I 63P 7IT 90M \\
\hline & & ZDV ABC ATV/r & & M54 & (RT) $215 \mathrm{I} / \mathrm{T}$ I0IR/K & \\
\hline & & & & & (P) I0I 63P 7IT 90M & \\
\hline \multirow[t]{4}{*}{10} & 2001 & ZDV & Month 3 & M3 & $103 N$ I8IC 2I5Y & NA \\
\hline & & ZDV & & M6 & $103 N$ I8IC 2I5Y & \\
\hline & & ZDV $3 T C$ LPV/r & & M24 & $\begin{array}{c}103 \mathrm{~N} 181 \mathrm{C} 184 \mathrm{~V} \\
215 \mathrm{Y}\end{array}$ & \\
\hline & & stop & & M48 & $\begin{array}{c}\text { I03N I8IC I84V/M } \\
215 Y / D\end{array}$ & $\begin{array}{c}103 \mathrm{~N} 181 \mathrm{C} 184 \mathrm{~V} / \mathrm{M} \\
215 \mathrm{Y}\end{array}$ \\
\hline \multirow[t]{5}{*}{ II } & 2004 & & Birth & MO & & \\
\hline & & ZDV 3TC & & MI & & \\
\hline & & $\mathrm{d} 4 \mathrm{~T} \mathrm{ABC} \mathrm{LPV} / \mathrm{r}$ & & M3 & $184 \mathrm{~V}$ & $184 \mathrm{~V}$ \\
\hline & & $\mathrm{d} 4 \mathrm{~T} \mathrm{ABC} L \mathrm{LPV} / \mathrm{r}$ & & M7 & & $184 \mathrm{~V}$ \\
\hline & & $\mathrm{d} 4 \mathrm{~T} \mathrm{ABC} L \mathrm{LPV} / \mathrm{r}$ & & M9 & $184 \mathrm{~V}$ & I $84 \mathrm{~V}$ \\
\hline
\end{tabular}

\section{REVERSION OF RESISTANCE MUTATION}

Resistance mutations in children

Patient Birth year Antiretroviral First HIV-I positive regimen sample

Resistance sampling date

HIV-I RNA

HIV-I DNA 
Table 2: Longitudinal resistance analysis in newborns infected with drug resistant HIV-I (Continued)

\begin{tabular}{|c|c|c|c|c|c|c|}
\hline \multirow[t]{3}{*}{6} & 1999 & ZDV & Birth & MO & $67 N / S$ & no mutation \\
\hline & & stop & & MI & & no mutation \\
\hline & & d4T ddI NFV & & $M I 2$ & no mutation & no mutation \\
\hline \multirow[t]{6}{*}{12} & 2004 & ZDV & Birth & Mo & 70R/K & no mutation \\
\hline & & ZDV & & M2 & 70R/K & no mutation \\
\hline & & stop & & M3 & no mutation & no mutation \\
\hline & & stop & & $M 12$ & & no mutation \\
\hline & & stop & & MI8 & & no mutation \\
\hline & & stop & & M24 & no mutation & \\
\hline
\end{tabular}

ZDV = zidovudine, 3TC = lamivudine, $d d l=$ didanosine, $d 4 T=$ stavudine, $A B C=$ abacavir, $N V P=$ nevirapine, EFV = efavirenz, NFV = nelfinavir, $\mathrm{LPV} / \mathrm{r}=$ lopinavir/ritonavir, ATV/r = atazanavir/ritonavir

RT: reverse transcriptase; P: protease; Persistent mutations in bold; Empty line: resistance test was not done

in New York State $[13,14]$. However, no information on maternal antiretroviral treatment and no maternal resistance genotyping were available in the latter studies.

The comparison of the maternal and neonatal drug resistance profiles pointed to two different mechanisms of acquisition of resistant variants by infants in the perinatal period (Figure 4). First, the infant could acquire drugresistant variants directly from the mother $(\mathrm{A})$, in one of two situations: i) the dominant variant in the mother also became dominant in the child, ii) a minor resistant variant transmitted by the mother was selected in the child during perinatal antiretroviral prophylaxis, particularly in the case of drugs such as nevirapine and lamivudine that have a low genetic barrier to resistance. Indeed, a single mutation is enough to confer high-level resistance to lamivudine or nevirapine. Moreover, selective pressure in the fetus is facilitated by the high transplacental diffusion of both these drugs [21,22]. Resistant mutations were detected early in infant lymphocytes. Clonal and longitudinal analyses showed that primary acquisition of resistant viruses was associated with long-term persistence in the infant's cellular reservoir; no matter what the subsequent treatment was.

In the second mechanism, the newborn initially acquires wild-type virus from the mother (B) (figure 4). Drug resistance can then arise during suboptimal zidovudine prophylaxis. Cloned viruses from the infants' cellular compartment were indeed wild-type, and wild-type viruses re-emerged when prophylaxis ended. Alternatively, minor resistant variants circulating in the mother may be undetectable at the clonal level in maternal samples, and/or resistant strains present in the female genital tract could be different from those circulating in the plasma [23].

Persaud et al. reported that drug-resistant HIV-1 in perinatally infected infants can fully populate the resting CD4+ $\mathrm{T}$ cell reservoir early in the course of infection and persist for years in replication-competent form [24]. Moreover, resistance acquisition and long-term persistence have been described after PMTCT with a single dose of nevirapine or lamivudine in resource-poor settings [25-27]. This long-term persistence in the cellular reservoir is reminiscent of the situation described in adults initially infected by resistant viruses [28-32]. As in adults, new resistance mutations can be acquired during suboptimal treatment with residual viral replication [31]. Our results underline the advantages of using HAART for PTMTC instead of suboptimal regimens that include drugs with a low genetic barrier to resistance and a long pharmacological half-life, as currently used in developing countries.

In the second mechanism, withdrawal of zidovudine prophylaxis led to the re-emergence of wild-type virus that had been archived during the primary infection. Once again, this resembles the situation in adults who acquire drug-resistant viruses during antiretroviral failure and in whom a dominant wild-type viral population re-emerges when antiretroviral therapy is stopped [33].

Our clonal analysis suggests that all archived viruses arising from the first mechanism are resistant (100\% resistant cellular clones in children \#9 and \#11), compared to about $10 \%$ resistance in those arising from the second mechanism (10\% resistant cellular clones in child \#12).

Importantly, the main difference between primary-infection in infant and adults was the use of sub-optimal antiretroviral prophylaxies in infants that could select for resistant viruses if the infection occurs.

We observed mutations associated with resistance to at least one antiretroviral drug in six children (10\%), with NRTI resistance in four, NNRTI resistance in two, and PI resistance in one. Recently, Lockman et al. showed that virologic failure of Triomune $e^{\circledast}$ was more frequent in infants who were previously exposed to a single dose of nevirapine rather than a placebo [34]. In contrast, Persaud et al. reported that RT resistance-associated mutations did not preclude the suppression of HIV-1 replication after 24 weeks of lopinavir/ritonavir-based HAART [24]. This result together with our findings supports the use of 

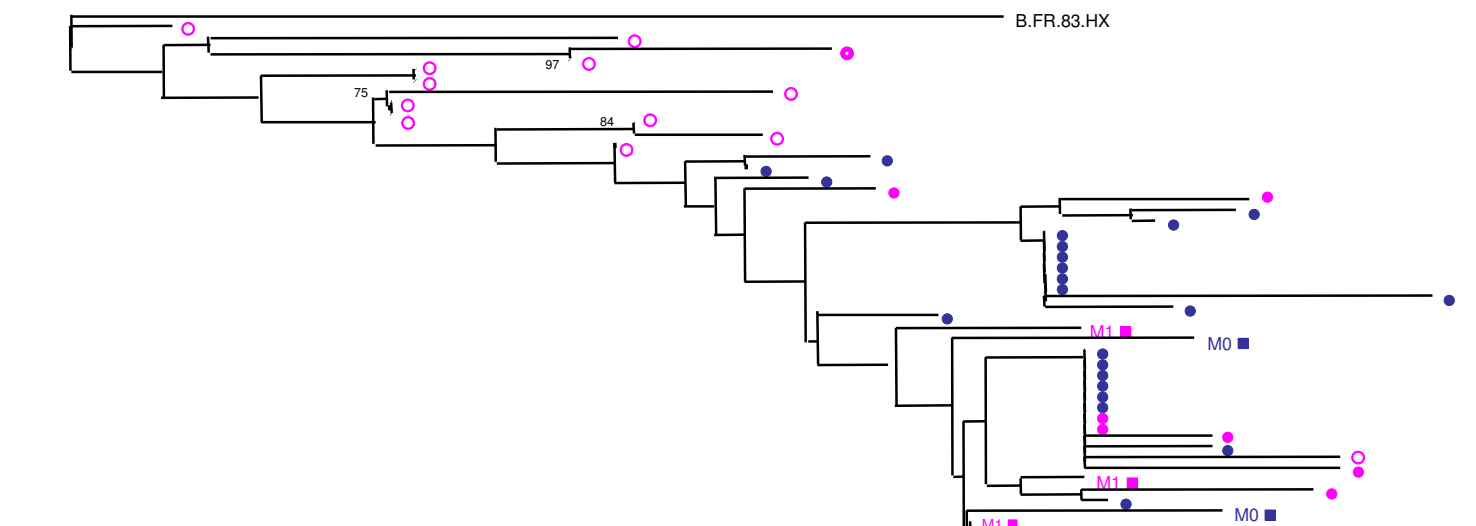

Child \#9
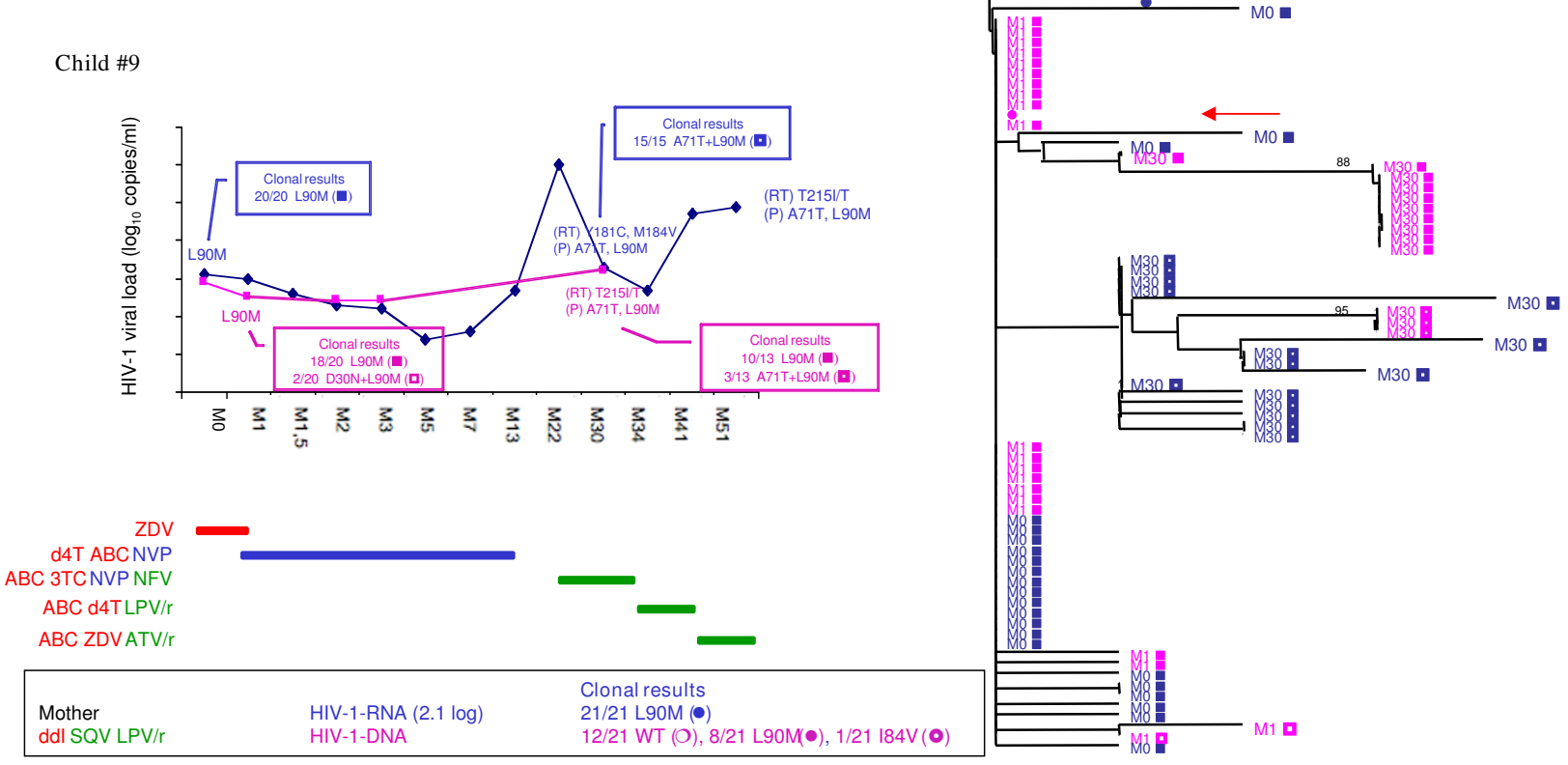

\section{Figure I}

Resistance analysis of HIV-I RNA and DNA from the mother-child pair \#9. Time course of HIV-I RNA and DNA levels in children with resistance mutations as detected by population-based sequencing and clonal analysis (box). Antiretroviral treatment is indicated above. Maternal antiretroviral treatment at delivery, viral RNA load, and the number of wild-type (WT) or resistant clones are indicated. In the phylogenetic tree, maternal viral clones are represented by circles and newborn viral clones by squares. $M$ indicates the time to genotype testing in month. Wild-type quasispecies are represented by open circles and squares, and resistant quasispecies by full circles and squares. HIV-I RNA results are in blue, and HIV-I DNA results are in pink. The arrow indicates the maternal viral clone closest to the infant's quasispecies.

boosted-PI regimens in children with resistance mutations or unknown resistance status.

In conclusion, our findings support resistance genotyping for children at diagnosis of HIV-1 infection, before treatment initiation, including children born to untreated mothers [35]. This approach could avoid jeopardizing drug treatment efficacy as demonstrated in adults [36]. Importantly, resistance testing in both the infant's plasma and lymphocytes would help to show whether resistance is likely to persist, with major implications for long-term treatment.
Our results also support current French recommendations to perform resistance genotyping in HIV-1-infected pregnant women in order to formulate both maternal and neonatal antiretroviral prophylaxis [5]. Finally, it is essential to use HAART and to avoid suboptimal regimens because early resistance acquisition can have drastic longterm consequences.

\section{Competing interests}

The authors declare that they have no competing interests. 


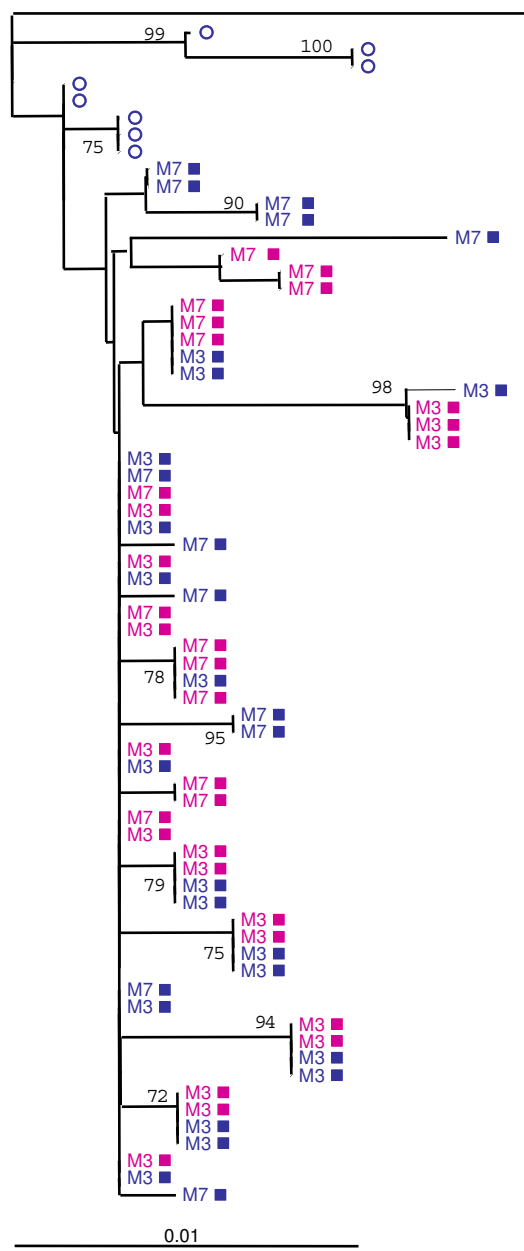

Child \#11
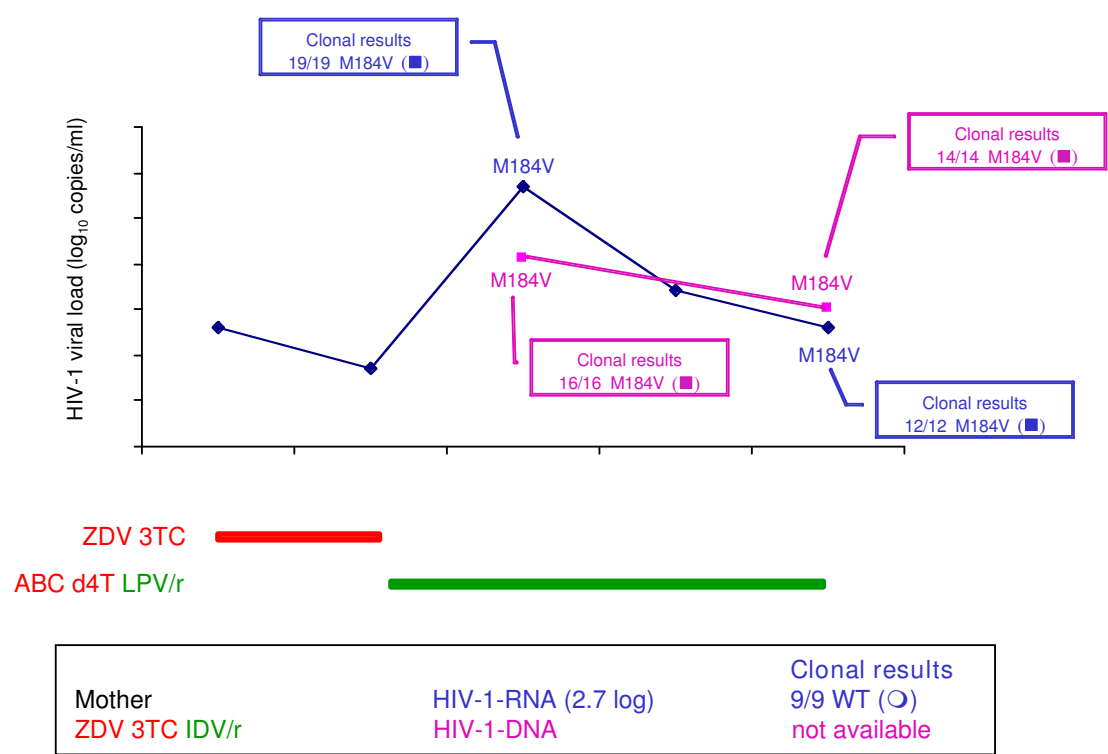

\section{Figure 2}

Resistance analysis of HIV-I RNA and DNA from the mother-child pair \#I I. Time course of HIV-I RNA and DNA levels in children with resistance mutations as detected by population-based sequencing and clonal analysis (box). Antiretroviral treatment is indicated above. Maternal antiretroviral treatment at delivery, viral RNA load, and the number of wild-type (WT) or resistant clones are indicated. In the phylogenetic tree, maternal viral clones are represented by circles and newborn viral clones by squares. $M$ indicates the time to genotype testing in month. Wild-type quasispecies are represented by open circles and squares, and resistant quasispecies by full circles and squares. HIV-I RNA results are in blue, and HIV-I DNA results are in pink. The arrow indicates the maternal viral clone closest to the infant's quasispecies. 

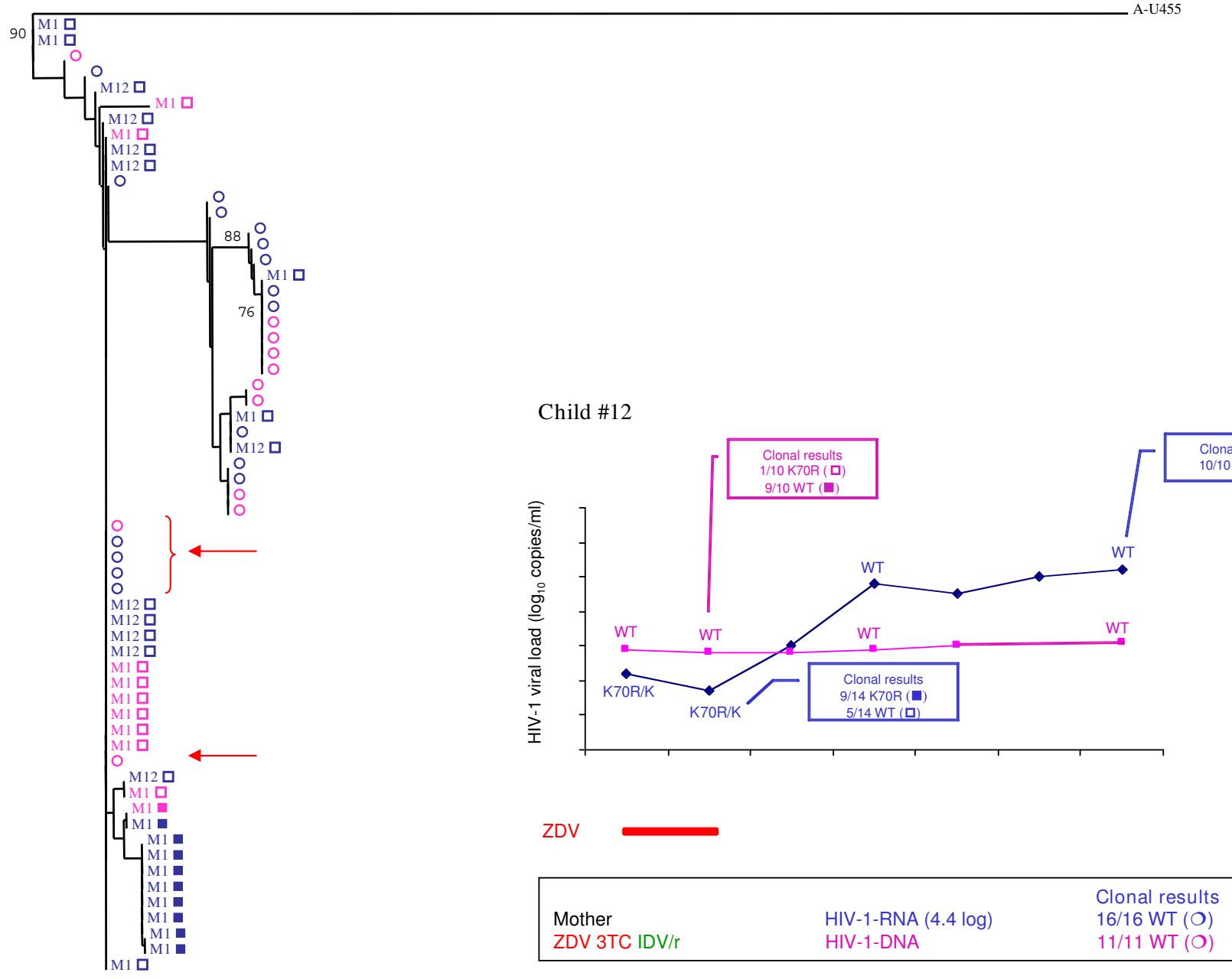

Figure 3

Resistance analysis of HIV-I RNA and DNA from the mother-child pair \#I 2. Time course of HIV-I RNA and DNA levels in children with resistance mutations as detected by population-based sequencing and clonal analysis (box). Antiretroviral treatment is indicated above. Maternal antiretroviral treatment at delivery, viral RNA load, and the number of wild-type (WT) or resistant clones are indicated. In the phylogenetic tree, maternal viral clones are represented by circles and newborn viral clones by squares. $M$ indicates the time to genotype testing in month. Wild-type quasispecies are represented by open circles and squares, and resistant quasispecies by full circles and squares. HIV-I RNA results are in blue, and HIV-I DNA results are in pink. The arrow indicates the maternal viral clone closest to the infant's quasispecies. 


\section{A Primary infection of the newborn with resistant HIV-1}

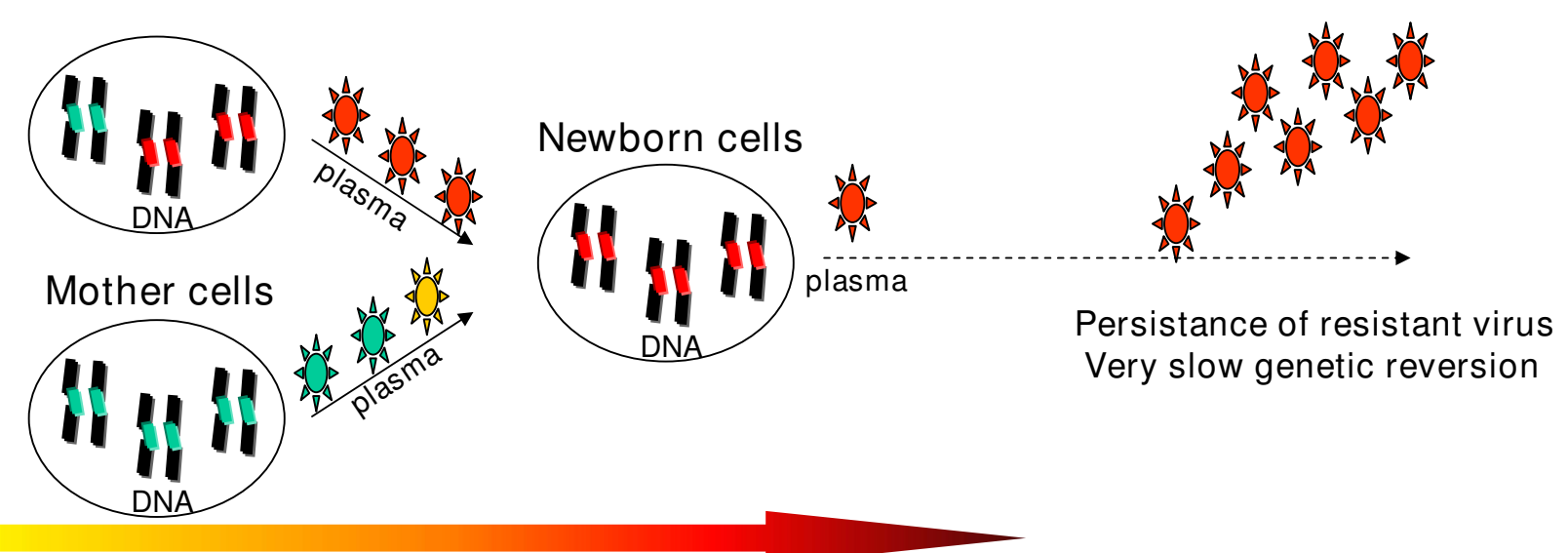

Transmission of resistant virus or primary infection under selective pressure of PTME

\section{B Primary infection of the newborn with wild-type HIV-1}

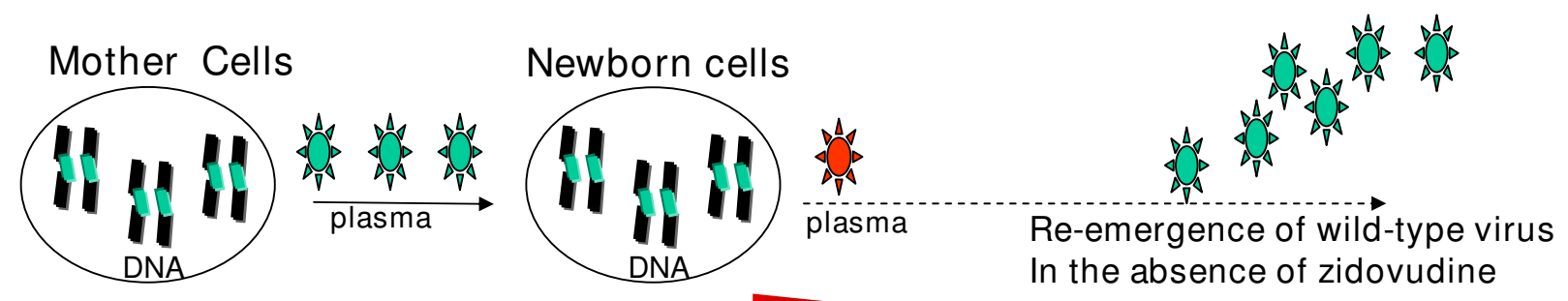

Transmission of wild-type virus and selection of resistant variants with PTME

Figure 4

Mechanisms of antiretroviral resistance acquisition in HIV-I-infected newborns. Wild-type viruses are shown in green and resistant viruses in red. The length of the yellow-to-red arrow indicates the duration of perinatal prophylaxis and thus the risk of resistance selection.

\section{Authors' contributions}

CD, MLC carried out the resistance studies, participated in the data interpretation and drafted the manuscript. DC carried out clonage and bulk resistance analysis. VS, MB participated in the sequence alignment. $\mathrm{SB}, \mathrm{CD}, \mathrm{AF}, \mathrm{LM}$ and RT participated in the design of the study. JW performed the statistical analysis. CR conceived of the study, and participated in its design and coordination. All authors read and approved the final manuscript.

\section{Acknowledgements}

We thank ANRS for their support of this study and the EPF ANRS cohort.

We thank Karima Hamreme and Thierry Wack for coordinating and monitoring the EPF database.

We thank the clinical investigators and all EPF ANRS cohort participants (see APPENDIX).
The following persons and institutions participated in the ANRS French Perinatal Cohort (EPF):

Hôpital d'Aix en Provence* (Tadrist B.); Hôpital Nord, Amiens (Decaux N., Douadi Y., Gondry, J.; Li Thiao Te V.; Schmit J.L.);Hôpital d'Angers (Fournié A.); Hôpital Victor Dupouy, Argenteuil (Allisy C. Brault D.); Hôpital Paris La Roseraie*, Aubervilliers (Rozan M.A.); Hôpital Robert Ballanger, Aulnay (Questiaux, E., Zakaria A., Goldenstein, C.);Hôpital Saint Claude, Basse-Terre* (Sibille G.); Hôpital de Bastia (Pincemaille O., Rusjan); Hôpital de la Côte Basque, Bayonne (Bonnal, F.; Cayla C.);Clinique du Blanc Mesnil* (Balde P.); Hôpital Saint Jacques, Besançon (Estavoyer J.M.Maillet, R;);Hôpital Avicenne, Bobigny (Bentata M.); Hôpital Jean Verdier, Bondy (Benoist L.; Bolie S., Bonier N.; Lachassine, E., Rodrigues, A.,); Hôpital Pellegrin, Bordeaux (Douard D.; Roux D., Schaeffer V.);Hôpital Ambroise Paré*, Boulogne Billancourt (Zenaty D.);Hôpital Clémenceau, Caen (Brouard J., Goubin P.); Hôpital André Rosemon, Cayenne (Elenga N.);Hôpital Beaujon*, Clichy (De Curtis A.);Hôpital de Creil (Carpentier B.; Duval-Arnould M., Kingue-Ekollo C); Hôpital Intercommunal, Créteil (Garrait V., Lemerle S., Pichon C., Richier C. Touboul, C.); Hôpital Béclère, Clamart (Bornarel D., Chambrin V., Clech L., Foix 
L'Hélias L., Labrune P., Schoen H); Hôpital Louis Mourier, Colombes (Crenn-Hebert C., Floch-Tudal C., Mazy, F., Hery E.; Meier C.,);Hôpital de Compiègne* (Lagrue A.); Hôpital d'enfants, Dijon (Martha S.; Reynaud 1.);Hôpital de Dourdan* (Ercoli V.);Hôpital de Dreux* (Denavit M.F.);Hôpital des Feugrais*, Elbeuf (Lahsinat K.); Hôpital Intercommunal, Evreux (Allouche, C.; Touré K...); Hôpital Francilien Sud, Evry-Corbeil (Chevron; Devidas A., Granier M., Guignier M., Lakhdari Y.; Marchand C. May A., Nguyen R, Turpault I); Hôpital de Fontainebleau (Routier C.); Hôpital Victor Fouche, Fort de France (Hatchuel Y. William, C.);Hôpital de Gonesse* (Balde P.); Hôpital Jean Rostand, Ivry (Jault T., Jrad I); Hôpital de Lagny (Chalvon Demersay A.,Froguel, E.; Gourdel B.);Hôpital du Lamentin* (Monlouis M.); Hôpital Les Oudairies, La Roche sur Yon (Aubry O., Brossier JP., Esnault JL,; Leautez S.; Perré P., Suaud I.); Hôpital de La Seyne sur Mer (Chamouilli J.M.);Hôpital Louis Domergue, La Trinité* (Hugon N.); Hôpital André Mignot, Le Chesnay (Hentgen V., Messaoudi F.); Hôpital de Bicêtre, Le Kremlin-Bicêtre (Fourcade C.; Fridman S.; Peretti D.);Hôpital Jeanne de Flandres, Lille (D'angelo S.; Hammou Y.,Mazingue F.,); Hôpital Dupuytren*, Limoges (De lumley L.); Hôpital de Longjumeau (Bailly-Salin, P.; Turpault, I.; Seaume H.); Hôpital Hôtel Dieu-Hôpital Debrousse, Lyon (Bertrand Y., Bertrand S.; Brochier C.; Cotte L., Kebaili K., Tache N., Roussouly, Mj; Thoirain V.,.); Hôpital François Quesnay, Mantes La Jolie (Delanete A., Doumet A., Granier F., Salomon JL.); Hôpital la Conception, Marseille (Cravello L.); Hôpital La Timone Marseille (Thuret I.); Hôpital de Meaux (Karaoui L., Lefèvre V.);Hôpital de Meulan* (Seguy D.); Hôpital Marc Jacquet, Melun (Le Lorier B.); Hôpital Intercommunal, Montfermeil (Dehlinger M.; Echard M.; Mullard C.;Talon P.); Hôpital Arnaud de Villeneuve, Montpellier (Benos, P.., Guigue N.; Lalande M.); Hôpital Intercommunal, Montreuil (Heller-Roussin B., Riehl C.,Winter.); Maternité Régionale A. Pinard, Nancy (Hubert C.); Hôpital de Nanterre* (Karoubi P.); Hôpital de Nantes (Brunet-François C.; Mechinaud,; Reliquet, V.) Hôpital de Neuilly sur Seine* (Berterottiere D.); Hôpital l'Archet-Fondation Lenval, Nice (Bongain A., Deville A., Galiba E. Monpoux F.), Hôpital Caremeau, Nîmes (Dendale-Nguyen J.); Hôpital Orléans (Arsac P.); Hôpital d'Orsay (Chanzy S., De Gennes C.; lsart V.); Hôpital Bichat, Paris (Bastian H. Batallan A., Matheron S.); Hôpital Boucicaut*, Paris (Lafay Pillet M.C.); Hôpital Cochin-Port Royal, Paris (Boudjoudi, N.; Firtion G., Fouchet, M.; Goupil, I., Pannier A.)); Hôpital Lariboisière, Paris (Ayral D., Ciraru-Vigneron N., Mouchnino G.); Hôpital des Métallurgistes*, Paris (Rami M.); Institut Mutualiste Montsouris*, Paris (Carlus Moncomble C.); Hôpital Necker, Paris (Boucly S., Blanche S., Maignan A.; Parat S., Rouzioux C.,Viard, JP.; Yamgnane, A.); Hôpital Notre Dame du Bon Secours, Paris (Aufrant C.); Hôpital Pitié Salpêtrière, Paris (Bonmarchand, M.; De Montgolfier l.; Edeb N., Lemercier D.; Marcel, S. Pauchard, M., Tubiana R.,);Hôpital Robert Debré, Paris (Faye A., Garion D., Leveille S.; Levine M., Ottenwalter A., Recoules A.)); Hôpital Saint-Antoine, Paris (Bui E., Carbonne B., Meyohas, Rodriguez J.); Hôpital Hôpital Saint Michel, Paris (Aufrant C.);Hôpital Tenon, Paris (Hervé, F.; Lebrette M.G.); Hôpital Trousseau, Paris (Dollfus C.Tabone MD, Vaudre G., Wallet A.); Hôpital Marechal Joffre, Perpignan (Bachelard G.; Medus M.);Hôpital Les Abymes, Pointe-àPitre (Bataille H.); Hôpital de Poissy-Saint-Germain en Laye* (Rousset M.C.); Hôpital René Dubos, Pontoise (Mouchnino G.); Hôpital Américain, Reims (Munzer M.); Hôpital Charles Nicolle, Rouen (Brossard V.); Hôpital de Saint-Denis (Allemon M.C., Bolot, P.; Dandris S.; Ekoukou D., Ghibaudo N., Khuong M.A.,); Hôpital Nord, Saint Etienne (Billiemaz K.); Hôpital de Saint Martin (Bissuel F. Walter, V.);Hôpital Esquirol*, Saint-Maurice (Robin M.); Hôpital de Sèvres* (Segard L.); Hôpital de Haute Pierre-Hôpital Civil, Strasbourg (Cheneau, M.; Entz-Werle N Favreau, J., Partisani M.);C.M.C. Foch, Suresnes* (Botto C.); Hôpital Chalucet, Toulon (Hittinger G.); Hôpi- tal Paule de Viguier, Toulouse (Antras, M.; Armand E.; Berrebi A., Tricoire J.) Hôpital Bretonneau, Tours (Besnier J.M., Nau P.); Hôpital Brabois, Vandoeuvre les Nancy (Neimann L.); Hôpital Paul Brousse*, Villejuif (Dussaix E.); Hôpital de Villeneuve Saint Georges (Chacé A., Guillot F., Matheron, I., Tilouche S.).

\section{References}

I. Rouzioux C, Costagliola D, Burgard M, Blanche S, Mayaux MJ, Griscelli C, Valleron AJ: Estimated timing of mother-to-child human immunodeficiency virus type I (HIV-I) transmission by use of a Markov model. The HIV Infection in Newborns French Collaborative Study Group. Am J Epidemiol 1995, I42:1330-1337.

2. Connor EM, Sperling RS, Gelber R, Kiselev P, Scott G, O'Sullivan MJ, VanDyke R, Bey M, Shearer W, Jacobson RL, et al:: Reduction of maternal-infant transmission of human immunodeficiency virus type I with zidovudine treatment. Pediatric AIDS Clinical Trials Group Protocol 076 Study Group. N Engl J Med 1994, 33 I: I |73-I 180.

3. Cooper ER, Charurat M, Mofenson L, Hanson IC, Pitt J, Diaz C, Hayani K, Handelsman E, Smeriglio V, Hoff R, Blattner W: Combination antiretroviral strategies for the treatment of pregnant HIVI-infected women and prevention of perinatal HIV-I transmission. J Acquir Immune Defic Syndr 2002, 29:484-494.

4. Warszawski J, Tubiana R, Le Chenadec J, Blanche S, Teglas JP, Dollfus C, Faye A, Burgard M, Rouzioux C, Mandelbrot L: Mother-to-child HIV transmission despite antiretroviral therapy in the ANRS French Perinatal Cohort. Aids 2008, 22:289-299.

5. Yeni P: Prise en charge meidicale des personnes infecteies par le VIH Flammarion edn Paris: Médecine-Sciences; 2008.

6. Johnson VA, Petropoulos CJ, Woods CR, Hazelwood JD, Parkin NT, Hamilton CD, Fiscus SA: Vertical transmission of multidrugresistant human immunodeficiency virus type I (HIV-I) and continued evolution of drug resistance in an $\mathrm{HIV}$ - I-infected infant. J Infect Dis 200I, I 83:1688-1693.

7. Masquelier B, Chaix ML, Burgard M, Lechenadec J, Doussin A, Simon F, Cottalorda J, Izopet J, Tamalet C, Douard D, et al.: Zidovudine genotypic resistance in HIV-I-infected newborns in the French perinatal cohort. J Acquir Immune Defic Syndr 200I, 27:99-104.

8. Siegrist CA, Yerly S, Kaiser L, Wyler CA, Perrin L: Mother to child transmission of zidovudine-resistant HIV-I. Lancet 1994, 344: $1771-1772$.

9. Fiscus SA, Adimora AA, Schoenbach VJ, Lim W, McKinney R, Rupar $D$, Kenny J, Woods C, Wilfert C: Perinatal HIV infection and the effect of zidovudine therapy on transmission in rural and urban counties. Jama 1996, 275:|483-|488.

10. Luzuriaga K, McManus M, Mofenson L, Britto P, Graham B, Sullivan JL: A trial of three antiretroviral regimens in HIV-I-infected children. N Engl J Med 2004, 350:247 I-2480.

II. Nolan M, Fowler MG, Mofenson LM: Antiretroviral prophylaxis of perinatal HIV-I transmission and the potential impact of antiretroviral resistance. I Acquir Immune Defic Syndr 2002, 30:216-229.

12. Palumbo P, Holland B, Dobbs T, Pau CP, Luo CC, Abrams EJ, Nesheim S, Vink P, Respess R, Bulterys M: Antiretroviral resistance mutations among pregnant human immunodeficiency virus type I-infected women and their newborns in the United States: vertical transmission and clades. I Infect Dis 2001, 184: I 120-II26.

13. Parker MM, Wade N, Lloyd RM Jr, Birkhead GS, Gallagher BK, Cheku $B$, Sullivan T, Taylor J: Prevalence of genotypic drug resistance among a cohort of HIV-infected newborns. J Acquir Immune Defic Syndr 2003, 32:292-297.

14. Karchava M, Pulver W, Smith L, Philpott S, Sullivan TJ, Wethers J, Parker MM: Prevalence of drug-resistance mutations and nonsubtype B strains among HIV-infected infants from New York State. J Acquir Immune Defic Syndr 2006, 42:6I 4-6I9.

15. Mayaux MJ, Teglas JP, Mandelbrot L, Berrebi A, Gallais H, Matheron S, Ciraru-Vigneron N, Parnet-Mathieu F, Bongain A, Rouzioux C, et al.: Acceptability and impact of zidovudine for prevention of mother-to-child human immunodeficiency virus-I transmission in France. J Pediatr 1997, I 3 I:857-862.

16. Descamps D, Delaugerre C, Masquelier B, Ruffault A, Marcelin AG, Izopet J, Chaix ML, Calvez V, Brun-Vezinet F, Costagliola D: 
Repeated HIV-I resistance genotyping external quality assessments improve virology laboratory performance. J Med Virol 2006, 78: 153-160.

17. Johnson VA, Brun-Vezinet F, Clotet B, Gunthard HF, Kuritzkes DR, Pillay D, Schapiro J, Richman DD: Update of the drug resistance mutations in HIV-I: Spring 2008. Top HIV Med 2008, 16:62-68.

18. Felsenstein J: The troubled growth of statistical phylogenetics. Syst Biol 200I, 50:465-467.

19. Avettand-Fenoel V, Chaix ML, Blanche S, Burgard M, Floch C, Kadidia T, Allemon MC, Warszawski J, Rouzioux C: LTR Real-time PCR for HIV-I DNA Quantitation in Blood Cells for Early Diagnosis in Infants born to Seropositive Mothers in HAART area (ANRS CO 0I). J Med Virol 2009, $81: 21$ 7-23.

20. Juethner SN, Williamson C, Ristig MB, Tebas P, Seyfried W, Aberg JA: Nonnucleoside reverse transcriptase inhibitor resistance among antiretroviral-naive HIV-positive pregnant women. J Acquir Immune Defic Syndr 2003, 32: I 53-I56.

21. Chappuy H, Treluyer JM, Jullien V, Dimet J, Rey E, Fouche M, Firtion G, Pons G, Mandelbrot L: Maternal-fetal transfer and amniotic fluid accumulation of nucleoside analogue reverse transcriptase inhibitors in human immunodeficiency virusinfected pregnant women. Antimicrob Agents Chemother 2004, 48:4332-4336.

22. Musoke P, Guay LA, Bagenda D, Mirochnick M, Nakabiito C, Fleming T, Elliott T, Horton S, Dransfield K, Pav JW, et al.: A phase I/II study of the safety and pharmacokinetics of nevirapine in HIV-Iinfected pregnant Ugandan women and their neonates (HIVNET 006). Aids 1999, 13:479-486.

23. Newstein M, Losikoff $P$, Caliendo A, Ingersoll J, Kurpewski J, Hanley D, Cerezo J, Ramratnam B, Cu-Uvin S: Prevalence and persistence of nonnucleoside reverse transcriptase inhibitor mutations in the female genital tract. I Acquir Immune Defic Syndr 2005, 38:364-366.

24. Persaud D, Palumbo P, Ziemniak C, Chen J, Ray SC, Hughes M, Havens P, Purswani M, Gaur AH, Chadwick EG: Early archiving and predominance of nonnucleoside reverse transcriptase inhibitor-resistant HIV-I among recently infected infants born in the United States. J Infect Dis 2007, 195: I 402-1410.

25. Chaix ML, Ekouevi DK, Peytavin G, Rouet F, Tonwe-Gold B, Viho I, Bequet L, Amani-Bosse C, Menan H, Leroy V, et al.: Impact of nevirapine (NVP) plasma concentration on selection of resistant virus in mothers who received single-dose NVP to prevent perinatal human immunodeficiency virus type I transmission and persistence of resistant virus in their infected children. Antimicrob Agents Chemother 2007, 51:896-90I.

26. Flys T, Nissley DV, Claasen CW, Jones D, Shi C, Guay LA, Musoke P, Mmiro F, Strathern JN, Jackson JB, et al.: Sensitive drug-resistance assays reveal long-term persistence of HIV-I variants with the KI03N nevirapine (NVP) resistance mutation in some women and infants after the administration of single-dose NVP: HIVNET 0 I 2. J Infect Dis 2005, 192:24-29.

27. Giuliano M, Galluzo C, Germinario E, Amici R, Bassani L, Deho L, Vyankandondera J, Mmiro F, Okong P, Vella S: Selection of resistance mutations in children receiving prophylaxis with lamivudine or nevirapine for the prevention of postnatal transmission of HIV. J Acquir Immune Defic Syndr 2006, 42:|3|-|33.

28. Brenner BG, Routy JP, Petrella M, Moisi D, Oliveira M, Detorio M, Spira B, Essabag V, Conway B, Lalonde R, et al.: Persistence and fitness of multidrug-resistant human immunodeficiency virus type I acquired in primary infection. / Virol 2002, 76: I753-I76I.

29. Delaugerre C, Morand-Joubert L, Chaix ML, Picard O, Marcelin AG, Schneider V, Krivine A, Compagnucci A, Katlama C, Girard PM, Calvez V: Persistence of multidrug-resistant HIV-I without antiretroviral treatment 2 years after sexual transmission. Antivir Ther 2004, 9:4I5-42I.

30. Delaugerre C, Marcelin AG, Soulie C, Chaix ML, Katlama C, Girard PM, Calvez V, Morand-Joubert L: Transmission of multidrugresistant HIV-I: 5 years of immunological and virological survey. Aids 2007, 2 I: 1365-1367.

31. Ghosn J, Pellegrin I, Goujard C, Deveau C, Viard JP, Galimand J, Harzic M, Tamalet C, Meyer L, Rouzioux C, Chaix ML: HIV-I resistant strains acquired at the time of primary infection massively fuel the cellular reservoir and persist for lengthy periods of time. Aids 2006, 20:159-170.
32. Little SJ, Frost SD, Wong JK, Smith DM, Pond SL, Ignacio CC, Parkin NT, Petropoulos CJ, Richman DD: Persistence of transmitted drug resistance among subjects with primary human immunodeficiency virus infection. / Virol 2008, 82:55।0-55।8.

33. Delaugerre C, Valantin MA, Mouroux M, Bonmarchand M, Carcelain G, Duvivier C, Tubiana R, Simon A, Bricaire F, Agut H, et al.: Reoccurrence of HIV-I drug mutations after treatment re-initiation following interruption in patients with multiple treatment failure. Aids 200I, 15:2189-2191.

34. Lockman S, Shapiro RL, Smeaton LM, Wester C, Thior I, Stevens L, Chand F, Makhema J, Moffat C, Asmelash A, et al.: Response to antiretroviral therapy after a single, peripartum dose of nevirapine. N Engl J Med 2007, 356:135-147.

35. Welles SL, Bauer GR, LaRussa PS, Colgrove RC, Pitt J: Time trends for HIV-I antiretroviral resistance among antiretroviralexperienced and naive pregnant women in New York City during 1991 to early 200I. J Acquir Immune Defic Syndr 2007, 44:329-335.

36. Chaix ML, Desquilbet L, Descamps D, Costagliola D, Deveau C, Galimand J, Goujard C, Signori-Schmuck A, Schneider V, Tamalet C, et al.: Response to HAART in French patients with resistant HIV-I treated at primary infection: ANRS Resistance Network. Antivir Ther 2007, I 2:1305-1310.
Publish with Bio Med Central and every scientist can read your work free of charge

"BioMed Central will be the most significant development for disseminating the results of biomedical research in our lifetime. "

Sir Paul Nurse, Cancer Research UK

Your research papers will be:

- available free of charge to the entire biomedical community

- peer reviewed and published immediately upon acceptance

- cited in PubMed and archived on PubMed Central

- yours - you keep the copyright

Submit your manuscript here:

http://www.biomedcentral.com/info/publishing_adv.asp
BioMedcentral 